\title{
Sekülerliğin Tezahürleri: Sezai Karakoç Şiirinde Mit ve Simge
}

\author{
Hasan TURGUT*
}

\section{$\ddot{O} \mathbf{z}$}

Sezai Karakoç, Türkiye'deki İslamcılık düşüncesinin inşasındaki en kritik figürlerden biridir. Karakoç şiirindeki kapsayıcı İslam anlayışı, seleflerinden ve çağdaşlarından büyük oranda ayrışır. Bu noktada Karakoç’un dinsel şiiri, kozmolojik göstergeler açısından elverişli yorumlar sunar. Pek çok yazarın kültürel alanı tasarlamasında pratik sonuçlar doğuran ortodoks İslami görüş, Karakoç’ta daha içermeci bir yapı gösterir. Söz konusu şiir, güçlü metafiziksel niteliklerine rağmen oldukça müphem bir doğaya sahiptir. Karakoç'un öznesi, seküler ve modern kentte yaşarken kendisini ara bir bölgede konumlandırır. Öznenin dünyevilik ve dinsellik arasındaki salınımı, sekülerliğin bariz kaynaklarından biridir. Talal Asad'a göre sekülerlik, farklı dünyalar arasında müzakere önerirken yeni ilişkiler, yakınlıklar ve etkileşimler sunar. Asad ayrıca modern Arap şiirindeki mitik atmosferle dinsel dogmacılık arasında bir karşıtlık kurar. Asad'ın analiziyle paralel biçimde, Karakoç şiiri seküler ve dinsel temalara devingen bir biçimde geniş bir alan açar. Karakoç'taki belirgin arayış, mit ve simgelere başvurarak dünyevi talepleri eskatolojik göndermelerle çözmeye çalışmaktır. Bu makale, Karakoç şiirini bir mücadele alanı hâline getiren karmaşık göstergelerin anlamını çözümlemeyi amaçlar.

Anahtar Kelimeler: Sezai Karakoç, Talal Asad, sekülerlik, simge, mit.

* Doktora Öğrencisi, Boğaziçi Üniversitesi, Sosyal Bilimler Enstitüsü, Türk Dili ve Edebiyatı Anabilim Dalı, İstanbul, Türkiye.

Elmek: turguthsn@gmail.com

https://orcid.org/0000-0002-4685-5077. 


\title{
The Signs of Secular: Myth and Symbol in Sezai Karakoç's Poetry
}

\begin{abstract}
Sezai Karakoç is one of the most important figures in the construction of Islamist thought in Turkey. The inclusive inclinations in Karakoç's poetry with respect to its particular understanding of Islam substantially distinguishes it from its predecessors and contemporaries. At this point, the cosmological signs in Karakoç's religious poetry offers bona fide interpretations. The orthodox Islamic view that provides practical means to numerous writers for shaping the cultural field, exhibits a more inclusive structure in Karakoç's poetry. His poetry displays a rather ambiguous character, despite its strong metaphysical attributions. Although the protagonists of Karakoç's poems live in the secular and modern city, they are situated in a liminal sphere. The protagonists' constant oscillations between worldliness and spirituality are an obvious reference to secularism. For Talal Asad, as secular offers the negotiation among the separate worlds, produces new relationships, intimacies, and interactions. Asad also formulates a dichotomy between the mythic atmosphere and the religious dogmatism in the modern Arabic poetry. In parallel with Talal Asad's analysis, Karakoç poetry affords an immense field to both secular and spiritual themes in a dynamic fashion. Karakoç's deliberate quest aims to resolve certain worldly demands by invoking myths and symbols in his poetry's eschatological references. This article aims to analyze the meaning of complex signs that renders Karakoç's poetry a contested zone for its readers.
\end{abstract}

Keywords: Sezai Karakoç, Talal Asad, secular, symbol, myth. 


\section{Extended Summary}

Sezai Karakoç is one of the most decisive personalities of modern Turkish poetry. With the birth of the Second New movement in the 1950s, Karakoç's poetry acquires a sui generis identity that exhibits both secular and spiritual qualities compared to its contemporaries. Karakoç's Islamic outlook does not promote an orthodox poetry due to its inclusive cultural character that is related to questions of secularism. According to Talal Asad, secularism is a liminal sphere between the worldliness and religiosity that proposes a dynamic mobility among different worlds. This adaptable quality of secularism establishes unorthodox and multiple outcomes in a given cultural field including interactions, intimacies, and affiliations that are cultivated among certain dissimilar circles. For Asad, romantic poets object to the modern world through the formation of a mythic order. In that sense, the mythic style turns into a means of resistance for the romantic movement against the material conditions of life. The origins of secularism in Turkish literature date back to the Tanzimat era in the first half of the 19th century but the paramount emergence of this tendency is with the Second New movement. Sezai Karakoç's poetical birth is full of secular meanings including certain worldly desires, metaphysical quests, and ambiguous pursuits.

The main subject of this article is the secularism in Sezai Karakoç's poetry that contains numerous worldly signs by virtue of the mythical and the symbolic. In the introduction part of the study, Karakoç's poetry's significance within the Second New movement is elaborated by delving into his prose regarding secularism, religiosity, and modern Turkish poetry. According to this prose, there are two Karakoç portraits in the beginning of the Second New movement: The first one aims to carve out a mutual literary understanding with his contemporaries, and the second one shows resistance to this literary circle's materialist worldview. On the one hand, Karakoç's poetry achieves a mythic and symbolic literary structure in the Second New movement and on the other hand, it distinguishes itself from the profane attitudes of the members of this group which designate their formal literary trajectories. In this respect, Karakoç's poetry offers a rather complicated and fraught experience for its readers due to its equivocal attributions. First part of this article delved into Karakoç's outlook on secularism, myths, and symbols. At first, the notion of secularism proposes a complex structure that consists of the profane and the sacred syn- 
chronously. Talal Asad's conceptualization of the secular merely contests to its profane meanings and offers an ambivalent framework related to the experience of modernity. For him, the knowledge that is derived out of this experience necessarily comprises the dual form of existence due to its paradoxical nature. Asad's heterodox analysis of secularism attributes equivalent values to the profane and the sacred as part of the modern experience in comparison with the strict interpretations of secularism. Secondly, Talal Asad's conceptualization of the mythical examines the metaphysical tendencies of romantic poets who take critical a stance against the capitalist worldview. According to this perspective, the myth plays a crucial role for the romantic movement's emphasis on the importance of an organic wholeness of things in the world. Romantic poets' understanding of the mythical expands a mystic order against the worldly poetical codes of the seculars. Due to the antagonistic direction that the myth takes, the poetic field in question attains a democratic openness that refuses certain homogenizing themes and approaches. Thirdly, in addition to the mythic promise, the symbol generates a unique imaginative pattern compared with the allegory that attributes a specific meaning the given reality (Here, this article refers to Hans-Georg Gadamer's conceptualizations of the allegory and the symbol). Hence, the myth and symbol turn into a set of secular means for the romantic poets to construct the spiritual worlds in their poems.

In the second part of the study, the signs of secularism in Karakoç's poetry are elucidated with the aid of the mythic and symbolic traces it reveals. With its endorsement of a symbolic and mythic identity, Karakoç's poetry forms a secular passage that does not deny any negotiation among opposing worlds. The main protagonists in Karakoç's poetry are situated in culturally distinct neighborhoods that present other perspectives and experiences. For this reason, Karakoç's poetry nullifies certain orthodox approaches and dichotomies via the inclusive literary model it entails. In comparison with other Islamist intellectuals of the 1950s and 1960s, Karakoç's cultural positioning exhibits compromising characteristics due to its thematic diversity that involves numerous spiritual and worldly contents. As a singular example, Karakoç's poetry generates a clear rupture in the Second New movement and also in Turkish literature.

Based on the literary analysis in this study, the concept of secularism acquires an extended network of meanings considering the romantic movement and also Sezai Karakoç's poetry. By delving into Karakoç's poetry that enables its own contradictive interpretations, this article argues for a new understanding with respect to the roots of secularism in Turkish literature in the second half of the $20^{\text {th }}$ century. 


\section{Giriş}

Sezai Karakoç şiiri, modernlik deneyiminden kaynaklanan bireysel ve toplumsal açmazlara ilişkin yanıtlar açısından güçlü göstergeler barındırır. Bu göstergeler, şairin İkinci Yeni etrafında gerçekleşen çıkışının, tek yönlü bir hareketten ibaret olduğu yönündeki yaygın okumayı geçersizleştirmektedir. Sezai Karakoç (1986a: 8), modernlikle karşılaşmanın şairi şeytani bir mücadele döngüsüne itmesine rağmen, dış dünyayı kuşatan gerçekliğin, içsel deneyimin sunduğu mistisizm kanalıyla dönüştürülebilir olduğunu savunur. Gündelik hayatın sağanağı, ebediyetin inşası aşamasında şairin hem güçlüklerden kurtuluşunun hem de onlara kapılışının kaynağıdır. Karakoç'un 1950’li yıllarda dönemin ana akım edebî kanonundan çıkmamak için çekinceli bir tavır olarak benimsediği mistik yönelişin zaman içinde temel bir izlek hâlini alışı, poetik düzlemde mümin öznenin zeminini hazırlar. İdeolojik ve kültürel bir unsur olarak dinselliğin şiir kanonundaki pozisyonu geniş bir tarihselliğe sahiptir; modern bir tavır biçiminde Mehmet Âkif Ersoy'da kökleşen bu atılımın Necip Fazıl Kısakürek ve mistisizme kayan yönleriyle Asaf Hâlet Çelebi gibi daha geç örneklerinden de bahsedilmelidir. Karakoç'un şiirsel varoluşu bu üç anıtsal ismin gölgesinde gerçekleşmiş gibidir. Ancak gelenek, estetikten çok siyasal alanda iş görmüştür; Karakoç söz konusu isimlerle benzer bir dinî duyarlılığa sahip olmasının getirdiği kültürel yükleri estetik varoluşunu tesis ederken unutma yoluna gidecektir.

Karakoç'un İkinci Yeni'yle mühürlenen doğuşu, onu kültürel göstergelerin hegemonya kurduğu bir alandansa biçimsel arayışların evla sayıldığı bir ortama bırakır. Yalçın Armağan (2011: 141), Kemalist modernleşme hareketinin ötekileştirdiği İslami duyarlılığın İkinci Yeni atmosferinde Karakoç’un varlığıyla kendisine yer bulmuş olmasını, onun ontolojik düzeyde estetik özerkliği öncelemesine atfeder. Türkiye'deki edebî kamplaşmaların ideolojik ve kültürel yakınlıklar ekseninde gerçekleşme tarzı, İkinci Yeni’nin türdeş olmayan şair kadrosuyla kesintiye uğramıştır. Sezai Karakoç’un buradaki konumu kendisinin de söz konusu dönemde kültürel arzuları merkeze koymamasıyla ilişkilidir. Bu bakımdan İkinci Yeni’nin yarı resmî yayın organı görünümündeki Pazar Postası dergisindeki 1958 tarihli "Dişimizin Zarı" isimli yazı, şairin çeşitli uzlaşımları gözetme hâlini ortaya koyar: 
"Laleli'den dünyaya doğru giden bir tramvaydayız. İşte yeni şiiri özetleyen bir mısra. $\mathrm{Bu}$ artık klasik şairin yolculuğuna benzemiyor. Klasik şair, azgın davetle neredeyse toprağın sonuna gider. Uçmak, kayıp gitmek, kaçıp dönmemek şartıyla. Orhan Veli akımında ise insan, Laleli'den çıkar bir yolculuğa ve tramvaya atlar; ama mutlaka Sirkeci'ye gider. Yeni gerçekçi akımda ise (çünkü bence, yeni akım, bir çeşit neo-realist akımdır), Laleli'den çıkar yolculuğa tramvayla ama dünyaya gider. Ben'in en küçük davranışı bile büyük bir haber gibidir. Yaşamı vardır ve önemlidir ama bir haber olarak. (...) Zaman önemini kaybetmiştir, insandır hep bu şiir. İsa ve İncil varsa bu şiirde, mistik ya da dinî bir şiir sanmayın. Tam anlamıyla laik bir şiirdir. Din bir dekor, ya bir benzetim ya bir sondaj aletidir. Yaşamayı çekip çıkarmak için bir alet” (Karakoç 1986b: 27-28).

Karakoç şiirine ilişkin birtakım erken dönemli ve süreklileşen temaları sergilemesi bakımından oldukça tipik olan bu pasajın, İkinci Yeni söyleminin içinde kalmaya dönük bir çaba sergilemeye çalıştığı açıktır. Yeni Gerçekçi akım adı verilen İkinci Yeni'nin, bu durumda Gerçekçi akım olan Garip şiirinin somut ve sürprizsiz havasından büsbütün farklılık taşıdığı söylenmektedir. Şaşırtmaca ve belirsizlik, İkinci Yeni şiirinin özneyi merkeze alan tutumunun temel özellikleri olarak gösterilmiştir. Ancak Karakoç, burada daha önce defalarca vurgulanan bu izleklerin yanına sekülerliği ekleyerek hem kendi şiirsel varoluşuna hem de İkinci Yeni’nin bütününe ilişkin oldukça çatışmacı bir gözlem yapmıştır. Bu gözlemin, şiirin özellikle erken döneminde yakın temaslar kurması açısından işlevsel katkılarından söz etmek gerekir; ne var ki sekülerlik vurgusunun, şairin ekseriyetle 1960'lı yıllardaki poetik inşasında çeşitli gerilimlere kaynaklık ettiği de belirtilmelidir.

Karakoç şiiri, İkinci Yeni söylemiyle görece barışçıl bir mesafe kurduğu seküler döneminin sorunlarını bütün hayatı boyunca sürdürmekten kurtulamamıştır. Nitekim şairin 1964 yılında yazdığı bir yazıda İkinci Yeni’den kopuşunu aktarırken kullandığı keskin dil, sorunların gölgesinin üzerinde gezinmeye devam ettiğini hissettirir:

"Sanat tutumum, genel dünya görüşümün bir bölümünden başka bir şey değildir. Onu bir sesin, yeni bir sesin sırtına yüklemekten ibarettir. Benim şiirim aşk, hürriyet, yaşayış ve ölüm gibi var olmanın dinamitlendiği noktalardaki trajik espriyi, irrasyonale ve absürde bulanmış Mutlak'1 zaptetmektir. Gittikçe şiirde bunu yapmak istiyor şiirim. Bunun için, başlangıçta sanat planımda görünüşte çok yakın bir noktadan çıktığım arkadaşlardan şiirim uzaklaşıyor. Ses ve biçim, motifler ve imajlarda, başlangıçta çok yakın olduğumuz şair arkadaşlardan git- 
tikçe o biçimi dolduran ve o sesi firlatan varoluşu idrak fark1 yüzünden ayrıl1yorum. Kişilik farkından. Ya da baştan beri olan bu farklılık gittikçe daha çok beliriyor" (Karakoç 1986b: 37).

Karakoç, İkinci Yeni'den çıkışını estetik dönüşümle değil, geçmişte de olan ancak çeşitli uzlaşımları sekteye uğratmamak adına silikleştirilen ontolojik farklılaşmayla açıklamaktadır. Şairin idrak düzeyi artık estetik öncelikleri gözetme noktasında işlevsizleşmiştir. Bu dönemde estetiğin ideolojik tahayyülün çeperiyle sınırlandırılması, Karakoç şiirini yoğun bir anlam örüntüsüyle donatmaya başlayacaktır. Sanatın mutlak aray1şında araçsallaştırılması, şiire içkin olan yapısal özerkliği bir hakikat rejiminin emrine sunmaktadır. Pazar Postası döneminde dünyanın açıklanması bakımından bir dekor olarak iş gören din, artık doğrudan doğruya sahnenin kendisi biçiminde ele alınmaya başlamıştır. Söz gelimi Laurent Mignon (2003: 136), yeni mutasavvıf şairlerden biri olarak tanımladığı Karakoç’taki bariz yönelimin, üsluplaştırılmış bir mekândaki gizem arayışı olduğunu savunur. Divan şiirinin soyut ve kapalı mistisizmi, Karakoç’ta modernlik tecrübesinin çıktısı olan uyuşmazlıklarla somut bir mecraya kavuşur. Bu noktada duyumsal bağlantıların, eskatolojik ilhamların gelişimi için sınırlayıcı bir kaynak hâlini aldığını da vurgulamak gerekir. Karakoç şiirinin bu sınırlılığa yanıt olarak, maveranın ontolojik bir merkez hâline gelmesi adına çeşitli stratejiler geliştirdiği ve edebî alanı metafiziğe özgü kavramlarla kurguladığı belirtilmelidir. Hiçbir şeyin başlangıçtaki biçimini muhafaza edemediği bir düzende Karakoç şiiri, mutlak âlemden gelen vahiylerle toparlanma yoluna gitmeyi seçer (Baş 2008: 472). Bu makale, Karakoç şiirindeki dünyevilikle dinsellik arasındaki çatışmaların çözümünde mit ve sembolün temel bir rol icra ettiğini iddia etmektedir. Karakoç, seleflerinden farklı olarak bu çatışmayı daha derin biçimde yaşayıp dinsel aşkınlıkla materyalist hayat koşulları arasında bir uyum yakalamaya çalışırken aşağıda daha kapsamlı gösterileceği üzere Talal Asad'ın sekülerizm tarifiyle örtüşen bir şiirsel alan yaratır. Şiirlerinde farklı dünyalar arasında diyaloğu önemseyen bir çerçeve kuran Karakoç, bu noktada mitin ve simgenin biçimsel olanaklarından yararlanmaktadır. Yine bir sonraki bölümde bazı kuramcıların görüşlerinden yardım alınarak tartışılacağı üzere, mit, değişik dünyalar ve anlayışlar arasında sunduğu süreklilik deneyimiyle; simge ise alegoriye kıyasla sağladığı yaratıcı muhayyile imkânıyla Karakoç şiirindeki seküler çoğulculuğun kaynağı olmaktadır.

Karakoç şiirinde, tanrısal mesajın kişinin rıza arzusuyla çakışma ânını işaretleyen vahiy, mitik deneyimin en bariz göstergelerinden biridir. Dolayısıyla modernlik deneyiminden kaynaklanan çürümenin panzehiri olarak görülen metafizik, İslam 
uygarlığının temel ilkesi olan mutlaklık âlemine giden yolda radikal taleplerden biri hâline gelir. Karakoç (1988: 6) bu dünyayı, öte dünyaya bir çıkma ve dipnot olarak tasarlamıştır. Ancak dünyanın, maveranın iz düşümüne dönüşümü bir sıfırlama eylemi değildir; Karakoç’un dinsel bir içgörüye dayandırdığı şiiri, kozmolojik göstergelerden yana elverişli okumalar sunar. Karakoç şiirini bir mücadele alanı hâline getiren de açmaz gibi görünen bu ikili harekettir. Mümin öznenin dünyayla ilişkileri öte âlemin tesisi açısından elzemdir; ne var ki inşanın maddi koşullarda gerçekleştirilmesi, özneyi sekülerlik halesiyle damgalı kılmaktadır. Karakoç’un öznesinin tarafgir biçimde bir seçim paradoksuyla lekelenmemesinin altında, bu şiirin dünyevilik ve dinsellik arasındaki geçişken kimliği yatar. Geçişken yapı hem dinsellik hem de dünyevilik yüklü lirizmin kaynağıdır. Karakoç, lirizmi, taşlaşmış maddi gerçekliğe bir cevap olarak şiirsel mesaisinin başat tekniği hâline getirmiştir. Buradaki lirik Adorno'nun deyişiyle (2008: 118), “dünyanın şeyleşmesine ve sınai devrimin hayattaki baskın güç hâline gelişinden beri insanların meta tahakkümü altına girişine karşı” kişisel ama evrensele doğru genişleyen bir muhalefet örgütler. Bununla birlikte, Karakoç'un lirik şiiri, metafizik ihtiyaçlarla dünyanın maddi talepleri arasında bir denge tutturmaya çalışırken çeşitli döngülerden geçmek durumunda kalır. Mistik bir çilecilikten, acının failleştirdiği bir öznelliğe, mitik bir kurtuluş düşüncesinden, simgeci bir gizem arayışına ve nihai olarak ruhsal bir diriliş felsefesine Karakoç şiirinin geniş tabanlı bir ilişkiler ağı vardır. Bu ağın, şairin dünya sürgününe kategorik olarak bazı ilhamlar zerk ettiği ve böylece sürgünü katlanılabilir kıldığg iddia edilebilir. Seleflerinin kültürel alanı tasarlamasında farklı düzeylerde dışlayıcı sonuçlar doğuran ortodoks İslami görüş, Karakoç’ta yerini daha katılımcı bir yapıya bırakır. Söz konusu şiiri, İslamcı ideolojinin diğer önemli figürlerinden uzaklaştıran da güçlü metafizik arzusuna rağmen kendisini çeşitli tikel durumların yatağı hâline getiren çoğul doğasıdır. Necmiye Alpay (2005: 132), Karakoç şiirinin tüm medeniyetleri ve dünya dinlerini arıtılmış tarih ve anlamlarıyla İslam çatısı altında diriltmek isteyen bir sisteme sahip olduğunu söyler. Karakoç poetikasının kapsayıcılık söylemi, İslam merkezli dokusuna karşın her türden kültürel göstergenin dolaşım özgürlüğünü garanti altına alan bir bakışa sahiptir. ${ }^{1}$

1 Necmiye Alpay'ın kapsayıcılık iddiasına yaklaşanlardan biri de Laurent Mignon'dur. Mignon “Türkçe Edebiyatta Haçın Gölgesi” isimli yazısında, aralarında Sezai Karakoç’un da olduğu çok sayıda Türk şairin Hıristiyan kültüründen tematik olarak etkilendiğini ve bu yolla şiirlerinin kültürel zeminini genişlettiklerini savunur: “Karakoç’un birçok şiirinde Meryem ve İsa figürleri Müslümanca ele alınıyor. Ne var ki Karakoç'un şairlik tanımında da önemli bir rol oynayan insanlığın çilesini çekme fikri, Hıristiyanların inandığı insanlığın çilesini ve günahlarını üstlenerek kendini feda eden İsa imgesine uymuyor değil doğrusu" (Mignon 2016: 34). 


\section{Sekülerlik, Mit ve Simge}

Sezai Karakoç’un İkinci Yeni’ye ilişkin sekülerizm okumasından vazgeçerken metafizik bir merkez yaratma çabasına girişmesi, modernlik deneyimiyle yüz yüze kalan şairlik konumunun bir sonucudur. Metafizik talebin, şairin diriliş söylemiyle kesişmesi, şiiri güçlü bir dinsel çerçeveye bağlar; ancak bu çerçevenin doğası bazı açılardan karmaşık örüntüler içermektedir. Bunun sekülerlikle ilişkileri biçimlendiren temel yönelimlerden biri hâline geldiği ve ara formlar üretme noktasında kışkırtıcı bir tartışma vadettiği belirtilmelidir. Ara formların Karakoç şiirindeki teknik göstergelerinin yorumlanmasında Talal Asad'ın sekülerlik konusunda kurduğu teorik çerçeve önemli imkânlar sunar. Asad, sekülerlik ve dinselliğin sabit kategoriler olmadığını söylerken bunları tanımlayacak evrensel bir özün yokluğuna işaret eder: "Seküler ne kendisini öncelediği varsayılan dinî olanın devamıdır (yani kutsal kökenin son aşaması değildir) ne de bundan basit bir kopuştur (yani, onun karşıtı, kutsal olanı dışlayan bir öz değildir)" (Asad 2016: 37-38). Asad'ın yaklaşımında, iki olgu arasındaki ikame ilişkisi kendiliğinden devre dışı kalmaktadır. Öte yandan, ikame ilişkisinin yokluğu olguların birbirlerini tüketmesine yol açmaz; hem sekülerlik hem de dinsellik çatışma ve müzakere ihtimalini dışlamadan bir arada yaşamaya devam ederler. Asad kutsal olanla din dışı arasındaki ayrımın modernleşmeci evrensel paradigma yoluyla literatüre girdiğini savunur: "Orta Çağ teolojisinde esas karşıtllk doğaüstü kutsal ile doğal din dışı arasında değil, her ikisi de aşkın güçler olan 'ilahi' ile 'şeytani' arasında ya da her ikisi de dünyevi kurumlar olan 'manevi' ile 'dünyevi' arasındaydı"' (Asad 2016: 45). Buradan hareketle, sekülerliğin ortaya çıkışı dinselliğin sönümlendiği bir karar ânıyla ilişkilendirilmez; dinsellik ve sekülerlik birbirlerine su taşıyan kategoriler olarak diyalojik zeminde temas kurmayı sürdürürler. ${ }^{2}$ Asad'ın okumasıyla sekülerliğin ya da kutsalın, ötekisi tarafından dışlandığı bir tasfiye mekanizması gündem dışı kalmaktadır. Ne kutsal din dışının hilafında çalışma çabasına girişecektir ne de din dışı kutsalın altını oymak için rasyonel müdahalelere soyunacaktır. Asad, iki olgunun da sabitleştirilemeyeceğini ve çeşitli stratejiler kanalıyla birbirlerinde gedikler açtıklarını vurgular.

Asad (2016: 69-71), özellikle Batılı romantik şairlerde büyüsü bozulan dünyayı yeniden büyüyle tanıştırmaya dönük arayışın mit kullanımını doğurduğunu söyler-

2 Asad'ın 1lımlı sekülerlik analizinin bir benzerini Özgür Taburoğlu da yapar. Taburoğlu, dünyevilikle kutsallık arasındaki keskin ayrımın geçersizliğini vurgularken daha müphem bir modelden söz eder: “'Ara biçimler'in bir yüzü kutsallıkta, diğer yüzü zındık, dünyevi taraftadır. Bir tarafı sonsuzluktayken, diğer tarafı şimdi ve buraya bakar. Ara biçimler yer ve ötesi arasında dururlar. Bu yönden hayaletlere benzerler; hem şimdi ve burada gibidirler hem de değildirler. Ara biçim ne tam olarak kutsaldır ne de zındık ne tam olarak maneviyat alanına aittir ne de dünyevi, gündelik mekâna. Geçirgendir ama tam olarak maddesiz, cisimsiz de değildir. Ara biçimlerin bu arada kalmış varlığı, kutsal ve dünyevi ikiliğini, karşıtlığını geçersizleştirir. Ötedeki varlıklar ara biçimler üzerinden yere karışır ve kutsallık, dünyeviliğe, zındıklığa dolanır. Kutsal ve din dışı alanlar ara biçimler üzerinden karışarak, birbirlerini dönüştürür” (Taburoğlu: 2008: 21). 
ken, modern Arap şiirinde tevarüs eden temsilin daha farklı bir amaca hizmet ettiğini savunur. Modern Arap şiirindeki mitik atmosfer, Müslüman toplumların sekülerleşme konusunda gösterdikleri düşünülen başarısızlığa bir yanıt olurken aynı zamanda tek tanrıcı dinlerin totaliter yasalarına karşı çoğul ve hatta isyankâr bir öneri sunar. Kapitalizmin metalaştırıcı karakterinin doğurduğu bencillik ve doğadan kopuşu, mitik anlatıların sunduğu organik uyumla çözmeye dönük iyimser çaba, romantik şairlerde güçlü bir tekniğe dönüşmüştür. Dünyanın seküler manzarasına ilişkin maneviyatçı bir muhalefet hâline gelen bu teknik, Arap şairlerde farklı bir yansıma bulmuştur. Asad, modern Arap şiirinin deneyimini, dinselliğin dogmatik ve hegemonyacı boyutlarına şerh düşmek biçiminde okumaktadır. Arap şiirinde dinselliğin tekçi karakteri, mitin getirdiği demokratik açıklıkla berhava edilir. Arap şairlerdeki mitik yönelimin altında, aynı zamanda sekülerliğin getirdiği pürüzlerle baş etme güdüsü yatmaktadır. Modern şiir kendisine mündemiç olan gerilimleri, sekülerliğin bir kanadı tarafından akıldışı sayılan mite başvurarak çözmeye çalışır. Bu çabanın sekülerle kutsalı birbirine yakınlaştırdığı ve böylece alanların dokusunda kısmi esneklikler yarattığı belirtilmelidir.

Mitin, seküler bir dünyada ontolojik zeminini yitiren şairler tarafından kopan bağların yeniden tesis edilmesinde tematik bir kaynağa dönüşümü, sembol ve alegori düzleminde de görülmektedir. Söz gelimi Paul de Man (2008: 221), Samuel Taylor Coleridge'in sembolle alegori arasında gerçekleştirdiği ayrımdan yola çıkarak temsil boyutunu irdeler. Buna göre, sembol, bir bütünselliğin parçası olarak sonsuz bir işaretler sistemine gönderme yaparken, alegorinin kendisinden menkul yapısı çağrışım potansiyellerini tekil bir anlama indirger. Alegorinin başka hakikatleri vazeden niteliğine karşın sembol, özdeşlik ihtimalini muhafaza etmeye devam eder. Hans-Georg Gadamer ise sembolün, keyfî biçimde seçilmiş ya da yaratılmış bir gösterge olmadı̆̆ 1 bilgisinden hareketle onun görülebilir olanla görülemeyen arasındaki metafizik ilişkiyi kurmaya muktedir olduğunu söylemektedir. Sembol, sanat yapıtlarının iç birliğine dayalı bir mekanizma üretirken, alegori daima başka bir şeye işaret eder. Sembolün kendi içindeki anlamı kristalize etmeye dönük çabası, alegorinin farklı ilişkisellikler kurma girişimleriyle bağdaşmaz: "Sembol duyularla algılanabilir olan ile duyularla algılanabilir-olmayanın örtüşmesidir; alegori duyularla algılanabilir olan ile duyularla algılanabilir-olmayanın anlamlı ilişkisidir" (Gadamer 2008: 101-103). Paul de Man ve Gadamer'in izahatları, sembolü, alegorik biçimin ekseriyetle tekçi yapısından farklılaştıran bir noktaya ulaştırır. Nitekim Orhan Koçak da (2011: 115) sembolü “küçük, kısmi, somut ve geçici olan şeyle büyük, soyut, ölçülmez ve aşkın olan arasında- 
ki karşılıklı anlayış, empati ve eşduyum ânı"na yerleştirir. Sembolün ikilikler arasında kurduğu dolaysız bağlantılar, sekülerlik deneyimiyle hemhal olan şairlere güçlü bir estetik alan imkânı sunmaktadır. Alegorinin belirli hakikatleri zerk eden kısıtlayıcı yapısı, sembolün dünyalar arasında geçişlere olanak tanıyan özgürleştirici jestleriyle ikame edilir. Dolayısıyla modern şiirde mitin çoğulcu karakterine, sembolün çok sesli bir çağrışım alanına açık nitelikleri eşlik etmektedir. Bir sonraki bölümde bu analizin Karakoç şiirindeki işaretleri irdelenecektir.

\section{Dünyalar Arasında Bir Şiir}

Çileci bir öznelliğin deneyimini sırtlayan Sezai Karakoç şiiri, Asad'ın kavramsallaştırmasında dinsellikle dünyevilik arasındaki sınır deneyimleri tanımlamak için iş gören seküler söylemin ve bu söyleme özgü mitik eğilimin göstergeleriyle doludur. Karakoç şiiri aynı zamanda ara formlar üretme noktasında Paul de Man, Gadamer, Coleridge ve Orhan Koçak gibi eleştirmenlerin izahatlarından yola çıkılarak sunulduğu şekliyle simgeden de faydalanmaktadır. Karakoç (1986b: 13), olgunluk döneminin ürünlerinden biri sayılabilecek "Kendini Arayan Şiirimiz" isimli yazısında, eski şiirin mazmun merkezli geleneksel biçimlerinin ve destan kaynaklı epik temsillerinin cari koşullarda yeniden üretilmesini savunurken yukarıdaki tartışmaya eklemlenmektedir. Bu açıdan şairin bir ütopya örneği olarak sunduğu "Fecir Devleti” şiiri kadim göndergesiyle tipiktir:

"Çă̆ırdığım fecirde yoğrulacak bir yapı

Dumanlar içinde

Alevler içinde bir Şeyh Galib'tir ustası

Taş- ses mercan kitap doğurgan yara

Firtına öncesi bir uygarlık

Dumanlar alevler kan içinde bir usta

Ve horoz çamaşır çarşambaları

Hayaletler mi

Bir tarihe hayalet dedin"

(Karakoç, 2000: 415).

Karakoç bir çağrıyla açtığı şiir boyunca tufandan önceki sahih bütünlük hâline gönderme yapar. Mitolojik talebin güçlü bir çizgiye dönüşmesi, şimdiki zaman deneyiminin çözümsüzlükleriyle ilişkilidir. Byung-Chul Han (2018: 29), mitolojik zamanın, kokusunu kaybeden tarihsel zamandan farklı olarak bir derinlik ve enginlik 
deneyimi sunduğunu belirtir. Güncel koşulların düz, cılız ve un ufak edici manzarası, burada mitolojik zamanın bütünlüklü zamansallığıyla ikame edilmektedir. Şair güncel zamandaki ontolojik yetersizliği aşmak için radikal biçimde geriye sıçrama yapmak durumunda kalır. Karakoç şiirinde öznenin tarihsel ahenkle kamaşma arzusunu kristalize eden Fecir Devleti tasarımı Büyük Amaç'ın mekânı olacaktır. Ancak bu tasarımda harap ev iskeletleri, bozgunda fetih düşü, kömür tabakası, madeni sis gibi sembollerde kendisini bulan bir yabancılaşmadan söz etmemek imkânsızdır. Şiirsel anlatıcının, diriliş gıyabında bir hafıza merkezi hâline getirdiği tarihin hayaletimsi içeriği çeşitli belirsizliklere kaynaklık etmektedir. Nitekim "Fecir Devleti” şiirine tevarüs eden idealin, Karakoç’un çatı katındaki evinde mütevazı bir hayalle sonlanması bir tür geri çekilme deneyimini anıştırır.

Karakoç şiirinde, giderek çıkmaza dönüşen gelgitler modern dünyadaki konumlanma güçlüğüyle dolaysız ilişki hâlindedir. Bunun ilk evrede münhasıran kısık sesle tebarüz ettiği örnekse "Balkon” şiiridir. Şairin 1957-1962 yılları arasındaki verimini içeren Körfez kitabında yer alan şiir melankolik bir atmosfere sahiptir:

“Çocuk düşerse ölür çünkü balkon

Ölümün cesur körfezleridir evlerde

Yüzünde son gülümseme kaybolurken çocukların

Anneler anneler elleri balkonlarin demirinde

İçimde ve evlerde balkon

Bir tabut kadar yer tutar

Çamaşırlarınızı asarsınız hazır kefen

Şezlongunuzu uzanın ölü

Gelecek zamanlarda

Ölüleri balonlara gömecekler

İnsan rahat etmeyecek

Öldükten sonra da

Bana sormayın böyle nereye

Koşa koşa gidiyorum

Alnından öpmeye gidiyorum

Evleri balkonsuz yapan mimarları"”

(Karakoç, 2000: 81).

Karakoç poetikasına ilişkin kimi eğilimleri sergilemesi bakımından katmanlı bir şiir olan “Balkon”, 1957 yılının İkinci Yeni tabanlı tarihselliğine kusursuz biçimde te- 
kabül eder. Karakoç’un sonraki şiirlerinde karşılaşılan tahkiyeci üslup, burada yerini minimal bir kelime kadrosuna bırakmıştır. Şairin, İkinci Yeni’nin estetik özerklik eksenli tutumu içinde kalmaya dönük çabası, şiirin akışkanlığına olumlu düzeyde katkı sunmuştur. Kentleşme olgusunun kırılganlıklarına odaklanan şiir, masumiyet arayışını bir ideal hâline getirir. Karakoç masumiyet kaybını balkon simgesiyle ifade ederken, kaybın öznesi olarak çocuk ve anneyi merkeze taşımaktadır. Çocuk ile anneye, içine ve evine bir tabut yalnızlı̆̆ oturan şiirsel anlatıcı eşlik etmektedir. Karakoç'un ufkunda, balkona ilişkin bütün göstergeler ölüme ayarlıdır; balkonun dünyası dirimin değil, ölümün mecrası olarak modern öznenin tükenişini katmanlı hâle getirir. Karakoç’un şiirdeki görece yavaş tempoyu, son kıtada bir hızlanma motifiyle dönüştürme yoluna gitmesi balkonsuz bir kent ütopyasının sonucudur. Şaire dair metafizik tezahürler bu erken dönemde sonrasıyla mukayese edilemeyecek düzeyde sembolik alanın içine gizlenmiştir. Georg Simmel (2009: 327), metropol olgusunun, bireyin elinden "her türlü maneviyat ve değeri söküp alan ve bunları öznel formlarından çıkarıp salt nesnel bir hayat formuna dönüştüren muazzam bir güçler organizasyonu” hâline geldiğini savunur. ${ }^{3}$ Kişiliğin bu koşullar altındaki oluşumu tinsellik ihtiyacını ezici biçimde billurlaştırmaktadır. Nitekim "Balkon”un evleri balkonsuz yapan mimarları koşarak öpmeye giden anlatıcısının tinsel kaygıları, zaman içinde Karakoç şiirinin başat niteliği hâline gelerek ilk evredeki çekinceli tavrı tedavülden kaldıracaktır. Dolayısıyla balkonsuz ev tasarımı, modernleşmenin yol açtığı travmatik deneyime metafizik bir noktayı sabitleyerek karşı çıkma eylemidir. Başka bir deyişle, modernist tekniklerin gıyabında güncel zamana taşırılmak istenen metafizik söylem, sekülerlik deneyimine yanıt verme çabasını içermektedir.

Karakoç’ta bir direniş formuna dönüşen sembolik tavrın altında çileci bir meydan okuma yatar. Modern dünya bilgisinin getirdiği trajik deneyim, ne olursa olsun maneviyat yükünden azade hâle gelememektedir. Bu aşamada, Karakoç şiirinin, sadece dinsellik yüklü içsel bir sürece hapsolmayıp çatışmacı bir tutum takınması, seküler bir dünyada yaşamanın zorunluluklarıyla ilişkilidir. Buna rağmen, Karakoç çeşitli dinsel çerçevelere ait sembol ve mitleri modernleşmeci bir perspektif içinde yeniden

3 Simmel, aynı yazısında metropol deneyiminin nesnel kültüründen neşet eden bir hegemonyanın kişilerde bireysel kültürü vurgulama ihtiyacını doğurduğunu da savunur: "Öte yandan, sahici şahsi renkleri ve benzersizlikleri ortadan kaldırmaya meyilli olan bu gayrişahsi içerikler ve değerler hayatı gittikçe daha fazla doldurmaktadır. Bu da bireyin şahsiyetinin çekirdeğini koruyabilmek için, sahip olduğu eşsizliği ve tikelliği öne çıkarmak adına elinden geleni ardına koymamasına yol açar. Kendisi için bile duyulabilir kalabilmesi amacıyla, bu şahsi unsuru abartmamak zorundadır. Nesnel kültürün aşırı büyümesi yüzünden bireysel kültürün küçülmesi, Nietzsche başta olmak üzere en uç bireyciliği vazedenlerin metropole duydukları buruk nefretin nedenlerinden biridir. Ama bu bireycilik vaizlerinin metropolde bu kadar tutkuyla sevilmelerinin, metropol insanının onları kendi karşılanmamış özlemlerini ifade eden birer peygamber ve kurtarıcı gibi görmelerinin nedeni de budur" (Simmel 2009: 328). 
yorumlayarak başat siyasi projesi dirilişi edebî planda gerçekleştirmeye devam eder. ${ }^{4}$ Beşir Ayvazoğlu (1997: 207), Türkçede ilk defa Asaf Hâlet Çelebi şiirinde belirginleşen mitik üslubun Karakoç'la birlikte anekdotik ve romantik bir çizgiye kaydığını iddia eder. Bunun şiire bir yandan güçlü bir tarihsel arka plan imkânı sunduğu ama öte yandan şairi bir tür imge sağanağı altında ilerlemek durumunda bıraktığı savunulabilir. Karakoç, klasik şiirin beyit merkezli ekonomik sembol repertuvarını uzun şiir tercihleriyle daha kapsamlı bir anlatıya dönüştürür. Şiirlerdeki görece uzun anlatısal tercihler, içeriğe atfedilen güçlü anlam ağıyla dolaysız irtibat hâlindedir. Şaire ilişkin kimi kültürelci yorumların mükerreren vurguladığı gibi Karakoç şiiri, "yok olma tehdidiyle karşı karşıya kalan bir uygarlığın yeniden kurulmasına yönelik bir umudu canlı tutar" (Akbakır 2012: 59). Karakoç’un kaybolan bir medeniyeti yeniden gün yüzüne çıkarmakla vazifelendirildiği yorumların kaynağı, poetikasının bütününe yayılan mitik kalıntılardır. Söz gelimi Fırat Mollaer, Karakoç'un Yitik Cennet'indeki endişe tonu yüksek dokuyu Batılılaşmanın doğurduğu aura çözülüşüyle ilişkilendirir: "Yitik Cennet'in saf kültürel bütünlük ve sahicilik fikri, mağduriyet söyleminin en önemli parçalarından birini oluşturur. Adem'le Havva'nın Cennette öncesiz ve sonrasızmışçasına mutlu bir hayatı yaşadıkları zaman gibiydi hayatımız Batının soluğu bize gelmeden önce" (Mollaer, 2016: 114). Yitik cennet arayışına paralel biçimde Karakoç poetikasındaki güç istencinin merkezinde Asr-1 Saadet düşüncesinden taşan arzular da etkin rol oynar. Modernleşmenin doğurduğu ruhsal boşluk, Karakoç’ta metafizik ethosun hafiza yoluyla hatırlatılması sonucunu doğurur (Andrews 2004: 18). Bunun giderek ilksel bir bütünlük hâlini kristalize ettiği ve mümin öznenin seküler dünyadaki zillet kapanına yakalanmasını takiben gerçekleşen yozlaşmayla şiiri teleolojik irtibatlar kurma çabasına ittiği belirtilmelidir:

"Portakal buğusudur yalayan seni beni

Kentte başlarken gece horozun terkettiği

Bir kadını havllyor taşıyor o ıssız köpekler ki

Kirmızı bir karpuzun ortasindan kesilen o köpekler ki

\footnotetext{
4 Laurent Mignon benzer bir tavra bu kez ters çevirmeyle Nâzım Hikmet’te de karşılaşıldığını söyler: "Nâzım Hikmet aynı imgeleri alıp, örneğin rubailerinde veya bazı oyunlarında yaptığı gibi, onları dinî ve gizemci anlamlarından çıkarıp marksizmin 1şığında yeniden yorumlamaktadır" (Mignon 2003: 141). Sezai Karakoç’un eskatolojik kültürü temel alarak gerçekleştirdiği evrimsel tarih anlayışı, Nâzım Hikmet’te Marksizm kaynaklı doğrusal bir çizgiselliğe ulaşır. Byung-Chul Han iki zaman arasındaki farklılığı şöyle nitelendirir: "Aydınlanma döneminde, özgül bir tarihsel zaman tahayyülü ortaya çıktı. Eskatolojik zamandan farklı olarak, ucu açık bir gelecek varsayıyordu. Bu tahayyülün zamansallığına sona doğru varoluş değil, yeniye doğru ilerleme hükmeder Bir anlamlılık edinir, kendi ağırlığı vardır. Çaresizlik içinde hızla kıyamete doğru ilerlemez. Hiçbir oluşsallık, hiçbir doğal sabit unsur bu zamansallığı döngüsel bir tekrara zorlayamaz. Böylece devrim de tamamen farklı bir anlam edinir. Yıldızlara özgü dairesel hareket tasavvurundan özgürdür artık. Döngüsel bir devirden çok, doğrusal, ilerleyen bir olaylar silsilesi belirler devrimin zamansallığını" (Byung-Chul Han 2018: 25).
} 
Deniz mi dedin ne denizi

Ben Kristof Kolomb'un uşă̆ değilim

Ben ırmakçıyım denizci değilim

Kulă̆ımda ne bir aşk ne de bir kürek sesi

Bir meydan uğultusu barbar bir inşaat sesi

Bir kere kente girdin

Bir kadını al onu yont anne olsun

Her kadını acıma anıtı bir anne olsun

Çocuklara açılan mavi kırmızı pencere anne

Sen bu şehrin sokaklarından geç sonsuz pencerelerle

Bir insanı al onu çöz çöz çocuk olsun"

(Karakoç, 2000: 129). "Köpük” şiirinin öznesi, aşina olduğu mekândan sökülüp atılmanın şaşkınlığını üzerinden atamamıştır. Kente giriş, eski yaşantının horoz ve köpek sesleriyle karpuz imgesinden mürekkep doğal atmosferinde yeni bir aşamaya işaret eder. Karakoç’un birçok şiirinde masumiyetle simgeleşen çocuk ve anne burada da merkezdedir; şiirsel anlatıcının aslına rücu edişi, özündeki yitik çocukluğu yeniden keşfiyle mümkün hâle gelir. Kentin en bilindik sıfatı burada barbarlıktır. Karakoç epik bir formda düzenlediği şiirde kent-çöl karşıtlığı kurar. Kentin felçli kadın karyolalı ve Azrail'in boyuna gerdeğe girdiği katastrofik sahnesinden çıkış hem şairin kendi çocukluğundan devşirdiği bütüncül manzaralara hem de genel insanlık tarihinde biriken dinsel ve mitolojik hakikatlere bağlanmıştır. Çocukluktan güncel zamana ulaşan parçalar, ağırlıklı olarak babanın anlatısında somutlaşan yerel dinsel mesajlarken, ortak tarih İbrahim, Musa, İsa ve Meryem kurguları üzerinden ilerleyen çileci mitolojik anlatılardan oluşur. Kadim kültürlerin Karakoç’taki yansımalarının gerek şiirin bir silsileye eklemlenmesi gerekse şairin güçlü bir ikonografik temsille eşleşmesi açısından pratik faydaları vardır. Karakoç eski kültürlerin dinî duyarlılık eksenli saflık arayışını, müşterek bir dua motifiyle işleyerek lirik bir bölgeye çekilir (Eroğlu, 2005: 51). Ne var ki, şairin sırtını dayadığı öte dünya birikimi, öznelliğin tanrısal bir konum tarafından sıfırlanmasını zorunlu kılmaktadır. Byung-Chul Han eskatolojik zamanın, ilerleme vadeden tarihsel zamanın doğrusal çizgisinden keskin biçimde farklı bir akışla malul olduğunu belirtir: "Eskatolojik zaman herhangi bir eyleme, bir tasarıya cevaz vermez. İnsan özgür değildir. Tanrı'ya tabidir. Kendini geleceğe doğru tasarlamaz. Kendi zamanını tasarlamaz. Sona, dünyanın ve zamanın nihai sonuna firlatılmıştır daha çok. Tarihin öznesi değildir. Düzene sokan, Tanrı'dır asıl” (Byung-Chul Han, 2018: 24-25). Karakoç şiiri hem Byung-Chul Han'ın sözünü 
ettiği zamanın sonuna firlatılmış edilgen öznenin deneyimini hem de zamanın sonuna ulaşmak için canhıraş bir mücadele veren modern öznenin çatışmalarını aynı anda içerir. Öznelliğin kutsallık içindeki kırılmalarının, Karakoç şiirinin seküler dünyadaki konumlanması açısından ikircikli sonuçlar doğurduğunu ifade etmek gerekir. Şairin gerek şiirlerine gerekse de düzyazılarına yansıyan seküler biçimler, kanonlaşma sürecindeki kimi gerilimlerin de habercisi olur. Karakoç şiirinin konumlandırılmasında yaşanan kararsızlıklar, poetik odağa ilişkin sorunların kendisi kadar önemli hâle gelir. Başka bir deyişle, Karakoç'un kendisinden menkul bir şiirsel bölgeye yerleş(tiril)mesinin arka planında şairin poetik çoğulculuğu etkin bir rol oynamıştır.

Şairin gelenekle ilgili bahiste mutlak bir şart olarak öne sürdüğü pirlerle alışveriş söylemi, özellikle İkinci Yeni’yle bağların seyreldiği dönemde giderek önem kazanmıştır (Karakoç, 1988: 18). Bu kapsamda Karakoç'un Batı'yla karşılaşmanın yarattığı tipolojileri yedi ayrı düzeyde işlediği şiirlerden biri olan "Masal"’n kendi kabuğuna çekilme jestiyle noktalanması şaşırtıcı değildir:

"En büyük Batı kentinin en büyük meydanında

Durdu ve tanrlya yakardı önce

Kendisini değiştiremesinler diye

Sonra ansızın ona bir ilham geldi

Ve başladı oymaya olduğu yeri

Başına toplandı ve baktılar Batılılar

$O$ aldırmadı bakışlara

Kazdl durmadan kazdl

Sonra yarı beline kadar girdi çukura

Kalabalık büyümüş çok büyümüşı̈̈

O zaman dönüp konuştu:

Batılılar!

Bilmeden

Altı oğlunu yuttuğunuz

Bir babanın yedinci oğluyum ben

Gömülmek istiyorum buraya hiç değişmeden"

(Karakoç, 2000: 412). "Masal”daki yedinci oğul, kaçınılmaz değişim çemberinden geçmemek için büyük Batı kentlerinden birindeki meydana kendisini gömerken görünür. Değişim kapanından kaçış ancak ölümün bir tercih hâline getirilmesiyle mümkün olacaktır. Karakoç'un diğer oğullara kıyasla saf kalabilmiş yedinci oğlu da yeryü- 
zünden silinmiştir. Şiir, son oğlun girdiği çukurda nurdan bir sütuna dönüşmesi ve bunu takiben onulmaz yarası olanların bu sütunu ziyaretleriyle görece iyimser bir sonuca ulaşır. "Masal" hem biçimsel hem de içeriksel düzeniyle geleneksel ve modernist formların kesiştiği bir arayüzü anıştırır. Yedinci oğlun, etrafını boşaltarak kendi kazdığı çukura girmesi sembolik düzeyde Karakoç şiirindeki sessizleşme hareketine gönderme yapar gibidir. "Masal"ın anlatıcısı etkilenme potansiyelini içerdikten sonra Harold Bloom'un altı revizyon kategorisinden biri olan askesis aşamasının niteliklerine çekilmiştir. Bloom'a (2008: 148) göre, etkilenme endişesine karşı başarılı bir savunma olan askesis aşamasında şair, diğer benliklerden ve dışsal olan her şeyin gerçekliğinden azade hâle gelen bir körleştirme programı uygular. 1969 tarihli "Masal” şiiri, Karakoç’un İkinci Yeni'den ayrılma evresinin sonlarına denk düşmesiyle, kendi merkezinin etrafını boşaltma hamlelerine dair güçlü işaretler barındırır. Ancak bu süreç aynı zamanda şairi yeni çağrışım imkânları bulmaya sevk etmektedir. Nitekim Karakoç şiirindeki mitik göndermelerin, İslam merkezde olmak üzere dinî aşkınlığın ve çileci öznelliğin büyük çizgilere dönüşmeleri, sekülerlik deneyiminin artık bir sorunsal olarak görülmeye başlandığı bu döneme rastlar.

Bu gerilimler nedeniyle Karakoç şiiri ne seküler kalabildiği İkinci Yeni ortamıyla ne de Müslüman olabildiği Büyük Doğu ve Hisar gibi maneviyatçı çevrelerle mutlak düzeyde barışçıl bir ilişki kurma şansı elde etmiştir. Ahmet Oktay 1960’lardan sonraki yazınsal iktidarın, Karakoç ismi etrafında bir sessizlik oluşturmayı bildiğini; bir ortak-yaşarlığ 1 (symbiosis) seç(e)meyen şairin de bu yazınsal iktidarı bir daha görmemek üzere dışladığını öne sürer. Oktay, Karakoç’un gözden uzaklaştırılmasının altında İslamcı ideolojinin siyasal alana taşınma arzusuna set çekme kaygısı olduğunu savunur: 'Karakoç için yalnızca 'mistik' bir sorun değildir din, dünyasal bir sorundur da. İslam devlette tenleşir. İşte sessizliğin nedeni” (Oktay 2001: 239-240). ${ }^{5}$ Oktay, Karakoç'un İslamcı söylemi toplumsal bir kurtuluş reçetesi hâline getirme çabasının, söz konusu yılların görece seküler ortamı için bir tehdit olarak görüldügüünü söylemektedir. Aynı şekilde Karakoç’un kendisi de, 1960’lı yılların aktivizm ortamında şiirlerini güncel siyasal duruma göre yenileyen eski yol arkadaşlarını değerlendirirken döneme yön veren kültürel endişeleri dışarıda bırakmaz. ${ }^{6}$ Ahmet Oktay, Karakoç’un

5 Mehmet Can Doğan da Ahmet Oktay’a benzer biçimde dışlanmanın altında şiirsel perspektifteki farklılaşmayı görür: "İlk şiirlerinden beri metafizik bir dikkat geliştirmiş olan Sezai Karakoç, 1960'larda bu dikkati, İslami bir duyuşla derinleştirip 'Diriliş' söylemiyle sistemleştirir. Kendi şiirinin ustası olma sürecinde geldiği nokta, Karakoç’un edebiyat kanonu tarafindan dışlanmasına yol açar. Öyle ki bu dışlama, sadece 1960'lar ve sonrasıyla da sınırlı kalmaz. Karakoç, modern Türk şiirinin en önemli hamlelerinden biri olarak kabul edilen İkinci Yeni şiirinden de dışlanmak, çıkarılmak istenir. Bu tutuma karşı o da edebiyat kanonunu dışlar" (Mehmet Can Doğan 2018: 340).

6 Karakoç gerek İkinci Yeni'deki arkadaşlarından gerekse de daha farklı çevrelere angaje olan şairlerden ilkesel düzeydeki 
"Bir Materyalist Şair” başlıklı Edip Cansever eleştirisine atıf yaparak Karakoç şiirindeki tinsel eğilimlerin en başından itibaren güçlü bir arayış olduğunu ifade etmektedir. İkinci Yeni’yle ilişkilerin henüz sıcak tutulduğu 1958 yılında kaleme alınan eleştiri, daha ismiyle bile bir seçim yapmaktadır. Materyalizmin, şiirin tinsel enerjisini boşaltan ve onu ölüme sürükleyen bir eğilim olduğu iddiası, bu eleştirinin temel tezidir. Bununla birlikte Oktay (2001: 253), Karakoç'un ilk dönem yazılarına dahi yansıyan metafizik yanlısı tutuma rağmen, onun materyalist şair Guellevic’ten çeviri yapmasını şaşırtıcı bulur. Oktay’a göre, İkinci Yeni’nin çoğu şair için kimi uzlaşımları içeren bir döneminin ürünü olan bu ilgi, Karakoç'un modernlikle gelenek arasında temas kurmasının sonucudur. ${ }^{7}$ Karakoç şiirinin metafizik kimliği maddi hayat koşullarının biçimlerini içermek zorunda kalmıştır. Onda seküler ve modern kente karşı çölü öneren çileci mümin öznenin ikameti, kendisine ara bir bölgede yerleşiklik bulmuştur. Dolayısıyla kentle mücadelenin onun yasalarına tabi olmadan gerçekleşmeyeceğini bilen öznenin, dünyevilik ve dinsellik arasında salınımı, sekülerliğin bariz kaynaklarından birine dönüşmektedir. Karakoç şiiri, gündelik deneyime açık yapısıyla paradoksal biçimde hem dünyadan kopuş hem de dünyaya dönüş vaadini aynı anda içermektedir (Oktay, 2001: 262). Karakoç'un temel söyleminde, seküler ve dinsel temalar devingen biçimde birbirleriyle ikame edilmiştir. Bu aşamada mit ve sembol kullanımının şair tarafından bir direniş aracına dönüştürüldüğünü vurgulamak gerekir. Karakoç (1986a: 41-42). "Mucize Medeniyeti ve Görüntü Medeniyeti” başlıklı yazısında, mucize medeniyetinin daha yüksek bir ruh dünyasına girişindeki vect hâlini somutlaştırdığını savunurken, görüntü medeniyetinin temel amacının, insanın duyumsal potansiyelleri-

ayrılışını şöyle ifade eder: "Sanatı, birtakım duyguları (ama o duygular ne olursa olsun, çağla ve insan içinin derin bölgesi, en alt bölgesiyle ilgili ne olursa olsun) heykeltıraş gibi yontmaktan ibaret sayanlarla, sanatı sadece doktrinlerin propaganda aleti sayanlardan ayrılıyorum. Bence sanat eseri, öyle bir varlık ve yaratıktır ki, bir açıdan insanı metafizik yüksek firınlarına sokup çıkarırken, öte yandan, tek başına bulutsuz ve sakin zeytin dalı, çam kokusu ve güvercin dolu yaz göklerinde, yüksek heyecanlarda dolaştırır. Sanat eserinde, 'saf yaratış' karşısında duyulan heyecan verici bir çarpıcılık gizlidir. Büyük bir şiiri okumadan önceki insanla okuduktan sonraki insan arasında bir fark vardır. Eser insanı değiştirmiştir; çarpmış, büyülemiş ve metamorfoza uğratmıştır" (Karakoç 1986b: 37). Ahmet Oktay’a göreyse Karakoç'un, İkinci Yeni çevresini yorumlama pratiği zamanla dinsel bir düzlemde gerçekleşir: “Karakoç’un çağdaşlarıyla paylaştığı tek duygunun, yaşanan zamanın ve toplumun parçalanmışlığı, bölünmüşlüğü karşısında duyulan tedirginlik, haksızlıklara karşı yöneltilen öfke olduğu söylenebilir. Ancak hemen belirtilmelidir ki, Karakoç’ta içerilmiş bulunan ütopya, çağdaşlarının karşıtındaki yönü imler. Çağdaşlar, buradan bakıldığında Karakoç açısından yitirilmiş kişilerdir. Günahlılık hâlinin değilse bile yanılmışlık hâlinin temsilcileridir" (Oktay, 2001: 251-252).

7 Ahmet Oktay, Karakoç'un modernist geleneğin ilerlemeci kanadıyla olan ilişkilerini Necip Fazıl Kısakürek'in içe kapanmacı yöneliminden ayırır: "Karakoç, egemen kültür ortamından henüz tam anlamıyla kop(a)madığı, bu yüzden de güncel düşüncelerle iletişim/bildirişimi koruduğu için modern ile gelenek arasında kurmayı istediği teması yenilikçi yazın içinde aramıştır. Ancak özellikle belirtmeliyim: Batı yenilikçiliği tarafından içerilme, kapsanma ya da o yenilikçiliğe eklemlenme söz konusu değildir. 'Temas' sözcüğ̈̈nü o yüzden seçtim. Karakoç, değişmekte olanı kavramaya, ona dokunmaya çalışmaktadır. Dokunacak ve kendi yönüne dönecektir. Dokunuş sırasında farklılı̆̆ının bilincindedir elbet. Ama vurgulamak gerekir: Bu bilinç, o yıllarda Necip Fazıl'da görüldüğü türden yalnızlıkçı (infiratçı) bir bilinç değildir. Mümin, henüz dışa, yabancıya kısaca öteki'ne yönelimlidir"' (Oktay, 2001: 253). 
ni kullanarak hayatın ağır fiziksel koşullarıyla uyuşmasını yine maddi dünya içindeki konforlu alanda belirginleştirmek olduğunu söyler. Nitekim, Karakoç şiiri de görüntü medeniyetinin seküler araçlarını seferber ederek mucize medeniyetinin metafizik umudunu içermeye dönük bir önerinin mecrası hâline gelmektedir.

\section{Sonuç}

Bu makale, Sezai Karakoç’un dünyevilikle dinsellik arasında sarkaç hareketleri yapan şiirinin, sekülerlik deneyimine açık bir pozisyonda yer aldığını temsilî şiirlerle göstermeye çalışmıştır. Karakoç, İkinci Yeni şiirinin seküler ortamı içinde görece karmaşık bir figür olarak çağdaşlarından çok farklı bir poetik öneride bulunmuştur. Karakoç şiirinde en başından itibaren siperde duran mit ve sembol tercihleri, özellikle etik ve dinsel kaygıların merkeze taşındığı angaje dönemde seküler bir doku taş1mıştır. Karakoç’un dinsel içerikli şiiri, mitin ve simgenin olanaklardan yararlanarak kutsalı başka formlarda yeniden üretmiştir. Dolayısıyla Karakoç’taki belirgin arayış, dünyevi taleplerin eskatolojik göndermelerle uyumlulaştırılması olmuştur. Bu çalışma, aynı zamanda Karakoç şiirinin münhasıran İslamcılık ekseninde okunamayacak düzeyde müphem ve heterodoks unsurlar barındırdığını göstermeyi denemiştir. Türk şiirinde Necip Fazıl Kısakürek'in başlangıç figürü olduğu İslamcılıkla mukayese edildiğinde Karakoç, çok daha kapsayıcı ve müzakereye açık bir İslamcı toplum modeli sunmuştur. Karakoç’un seküler hayat koşullarında başka dünyalarla diyalog ve etkileşimi esas alan tercihlerde bulunması, onu, kendi şiirsel hakikatini ihlal eden bir şair hâline getirmemiş; tam aksine bu yolla şiirine içkin olan açıklığa daha çok yaklaştırmıştır. Hakikatin şiir yoluyla tanınmasındaki çeşitlilik, başka bir düzeyde Karakoç'u kozmosun diğer veçheleriyle buluşturmuştur. 


\section{Kaynakça}

Adorno, Theodor W (2008), Edebiyat Yazıları, Sabir Yücesoy, Orhan Koçak (Çev.) İstanbul: Metis Yayınları.

Akbakır, S1ddık (2012), “Yoktur Gölgesi Türkiye'de”: Sezai Karakoç, İstanbul: Turkuvaz Yayınları.

Alpay, Necmiye (2005), Yaklaşma Çabası, İstanbul: Kanat Yayınları.

Andrews, Walter G (2004), "Stepping Aside: Ottoman Literature in Modern Turkey”. Journal of Turkish Literature, S. 1, s. 9-32.

Armağan, Yalçın (2011), İmkânsız Özerklik, İstanbul: İletişim Yayınları.

Asad, Talal (2016), Sekülerliğin Biçimleri, Ferit Burak Aydar (Çev.), İstanbul: Metis Yayınları. Ayvazoğlu, Beşir (1997), Geleneğin Direnişi, İstanbul: Ötüken Yayınları.

Baş, Münire Kevser (2008), Diriliş Taşları: Sezai Karakoç’un Düşünce ve Sanatında Temel Kavramlar, İstanbul: Lotus Yayınları.

Bloom, Harold (2008), Etkilenme Endişesi, Ferit Burak Aydar (Çev.), İstanbul: Metis Yayınları. de Man, Paul (2008), Körlük ve İçgörü: Çağdaş Eleştirinin Retoriği Üzerine Denemeler, Ferit Burak Aydar (Çev.), İstanbul: Metis Yayınları.

Doğan, Mehmet Can (2018), Modern Türk Şiiri, İstanbul: Yap1 Kredi Yayınları.

Eroğlu, Ebubekir (2005), Modern Türk Şiirinin Doğası, İstanbul: Yapı Kredi Yayınları.

Gadamer, Hans-Georg (2008), Hakikat ve Yöntem, Hüsamettin Arslan, İsmail Yavuzcan (Çev.), İstanbul: Paradigma Yayınları.

Han, Byung-Chul (2018), Zamanın Kokusu: Bulunma Sanatı Üzerine Felsefi Bir Deneme, Şeyda Öztürk (Çev.), İstanbul: Metis Yayınları.

Karakoç, Sezai (1986a), Günlük Yazılar III, İstanbul: Diriliş Yayınları.

------. (1986b), Edebiyat Yazıları II, İstanbul: Diriliş Yayınları.

------. (1988), Edebiyat Yazıları I, İstanbul: Diriliş Yayınları.

------. (2000), Gün Doğmadan, İstanbul: Diriliş Yayınları.

Koçak, Orhan (2011), Bahisleri Yükseltmek: Turgut Uyar Şiirinde Kendini Yaratma Deneyimi, İstanbul: Metis Yayınları.

Mignon, Laurent (2003), “Kaldırımlar'dan Monna Rosa’ya”, Hece, S. 73, s. 135-145.

- (2016), Edebiyatın Sinırlarında, İstanbul: Evrensel Yayınları.

Mollaer, Fırat (2016), Tekno Muhafazakârlı̆̆ın Eleştirisi, İstanbul: İletişim Yayınları.

Oktay, Ahmet (2001), Şairin Kanı: Yazınsal Eleştiriler I (1954-2000), İstanbul: Yapı Kredi Yayınları.

Simmel, Georg (2009), Bireysellik ve Kültür, Tuncay Birkan (Çev.), İstanbul: Metis Yayınları.

Taburoğlu, Özgür (2008), Dünyevi ve Kutsal: Modernlerin Maneviyat Arayışları, İstanbul: Metis Yayınları. 